\title{
Assessing the Papuan Government's Policy for Tackling the Spread of Coronavirus (COVID-19)
}

\author{
Johni R. V. Korwa ${ }^{1}$, Diego R. De Fretes ${ }^{2}$, Meyland S. F. Wambrauw ${ }^{3}$, Jackson \\ Yumame $^{4}$, Christine O. I. Sanggenafa ${ }^{5}$, Reni Shintasari ${ }^{6}$, Ferinandus L. Snanfi ${ }^{7}$ \\ ${ }^{1}$ Corresponding Author, International Relations, Faculty of Social and Political Science, \\ Cenderawasih University (email: korwajohni@yahoo.com) \\ 2,3,4,5,6,7Faculty of Social and Political Science, Cenderawasih University
}

\begin{abstract}
This paper aims to assess the Papuan government's policy for preventing the spread of COVID-19 through the shutdown of travel to the region based on the Papua joint statement. Excluding the transportation of goods, Papua was the first province in Indonesia to restrict entry into the region by both sea and air travel. To analyse the Papuan government's policy, Edwards' theory of policy implementation was adopted. Using first-hand interviews, observations, and library research, this paper argues that the government of Papua has made the right decision to close its borders, despite challenges, as part of a strict policy to protect the region from COVID-19. It is also worth noting that although five regions selected for this study (Jayapura City, Mimika, Biak Numfor, Merauke and Yapen Regency) reflected variations between one another in policy implementation, they all had expressed how the local government in Papua was doing the best they could to eradicate COVID-19. The use of theoretical frameworks (communication, resources, dispositions, and bureaucratic structures) as part of policy implementation had also been effective, despite that some parts need to be improved. The results of this study include recommendations for effective coordination among policymakers, the availability of laboratory testing, adoption of evidence-based policies and improving the health system in Papua.
\end{abstract}

\section{Keywords:}

Covid-19; Indonesia; Papua government; policy

\section{Introduction}

The world is currently experiencing unprecedented challenges from Coronaviruscommonly known as 'COVID-19' - that is affecting communities and governments all over the world. The first case of the COVID-19 was found in Wuhan City, China and reported by Dr. Li Wen Liang via social media -through his uploads to Weibo and WeChat - on 30 December 2019 (Hua \& Shaw, 2020; Yang et al., 2020)which started in Wuhan in China in early December 2019, brought into the notice of the authorities in late December, early January 2020, and, after investigation, was declared as an emergency in the third week of January
2020. The WHO declared this as Public Health Emergency of International Concern (PHEIC. At that time, he warned his fellow medics to be careful in dealing with mysterious new diseases (COVID-19). Due to his upload, on January 3 Liang dealt with the local police who later forced him to apologize for "making false comments" on the internet ( $\mathrm{Zhu}, 2020)$. Even though Liang was infected with the COVID-19 and subsequently died in February 2020, most people considered him a whistle-blower who helped raise awareness of COVID-19 cases to the public sphere (Enos, 2020; "Li Wenliang", 2020). On 11 March 2020, WHO officially declared the COVID-19 outbreak a global 
pandemic and this was followed by reports of confirmed cases from a number of countries (Ducharme, 2020.)

In Indonesia, President Jokowi officially announced details about two Indonesians who had tested positive for novel COVID-19 on 2 March 2020. President Jokowi stated that the two people (a 64-year-old and her 31-yearold daughter) had directly interacted with a Japanese citizen who had tested positive in Malaysia after visiting Indonesia in early February (Gorbiano, 2020). Almuttaqi (2020) observed that these two people apparently found out about their positive test results after listening to the announcement issued by the President in the public news; prior to direct notifications sent by the health workers. On 15 March, President Jokowi called for 'social distancing' through the reduction of out-ofhome activities, “...It's time for us to work from home, to learn from home, and to worship at home" (Purnamasari, 2020). The purpose of the announcement was to not only enable the government to reduce transmission but also maintain safety and protection in the midst of COVID-19. Since the first announcement of infected cases in early March, the number of confirmed COVID-19 positive cases has increased significantly. As of $23 \mathrm{March}$, there have been a total of 579 cases, 49 dead and 30 recovering ("Update Corona 23 Maret", 2020).

On 24 March, as the central government still called for social distancing, the governor of Papua, Lukas Enembe, released a joint statement in consultation with Forkopimda (a regional leadership coordination forum), regents/mayors and several other stakeholders (Surat Gubernur Papua, 2020). The statement expanded on the central government's social distancing policy by advising the Minister of transportation in Jakarta that entry into the region by both sea and air travel would be restricted, excluding the transportation of goods. Papua became the first province in Indonesia to close its borders to prevent the spread of COVID-19 to the region, coming into effect on 26 March 2020 (Dzulfaroh, 2020; Koran Fajar Indonesia, 2020). This decision was later followed by Tegal (30 March 2020) and Tasikmalaya (31 March 2020). Such response implies that the local government understands the character of the region very well and is aware of what decisions are best for the region. Papua needed more than just social distancing, thereby closing the travel for a while was required. In this context, Papua could become an example of how a local government highly prioritized the safety of its citizens and adopted stricter COVID-19 policies than the central government.

Korwa (2020) argued that the policy can be seen as a means of protection for the people of Papua, particularly indigenous ones. It also expressed distrust in the central government's ability to suppress human-tohuman transmission of COVID-19, which was crucial considering the unpreparedness of health facilities in the region. Although Governor Enembe had said that the joint statement only limited the movement of people, his decision was contrary to the instructions of the central government (Mawel \& Mambor, 2020; Nugraheny, 2020). It became a matter of concern because decisions on social restrictions in a region, including closing travel, were the authority of the central government; not the province - and in this case, it was the Minister who administers government affairs in the health sector as stipulated in Government Regulation Number 21 of 2020 Article 2 paragraph 1. Accordingly, this topic becomes interesting for further study. There have been many articles related to dealing with COVID-19 at the national level (Apresian, 2020; Martha, 2020; Morfi et al., 2020; Pakpahan, 2020; Telaumbanua, 2020; Widaningrum, \& Mas'udi, 2020), however, many of these authorities are not paying specifically focused attention towards the events at a regional level, including in Papua. Therefore, this article will try to fill this gap. 
This paper argues that the government of Papua has made the right decision to close its borders, albeit facing challenges, as part of a strict policy to protect the region from COVID-19. It also maintains that although five regions selected for this study (Jayapura City, Mimika, Biak Numfor, Merauke and Yapen Regency) reflected variations between each other in policy implementation, they all had expressed how the local government in Papua was doing the best they could to combat COVID-19. The paper is structured as follows: first, it presents the theoretical debates to justify the use of a theory to analyse the policy. Second, it explains the methods used including primary and secondary data. Third, it documents the results obtained in several sub-sections (identification of policies, current conditions, and the impacts). Fourth, it examines the Papuan government's policy which focuses on breaking the chain of COVID-19 transmissions. To do that, a theory developed by Edwards will be used. The final section provides conclusions and suggestions.

\section{Theoretical Debates}

Edwards and Sharkansky (1978, p.2) defined public policy as "What governments say and do, or do not do... It is goals or purposes of government programs... The important ingredients of programs... The implementation of intention and rules." Edwards (1980) in his book Implementing Public Policy builds on this definition, focusing on how to specify prerequisites for policy success as well as identifying barriers to successful policy implementation. In doing so, Edwards proposed four variables to analyze the implementation of a policy: communication, resources, dispositions or attitudes, and bureaucratic structures. Effective communication is vitally important to make sure the instruction is clearly understood by the person who will then carry out the orders. "Orders to implement policies must be transmitted to the appropriate personnel, and they must be clear, accurate and consistent"(Edwards, 1980, p.10). Resources also play a pivotal role in ensuring that implementers are capable of implementing effective policies.

The disposition or attitude is conceived as a commitment of implementers to pursue policies. "If implementation is to proceed effectively not only must implementers know what to do and have the capability to do it, but they must also desire to carry out a policy" (Edwards, 1980, p.11). Last but not least, bureaucratic structures can also influence the way in which policies are conducted. In this context, Edwards focused on two elements of the bureaucracy of the administration, which are Standard Operational Procedure (SOP) - a guideline containing written instructions to carry out work in accordance with administrative functions and processes; and fragmentation - an effort to divide the responsibility of a policy into several different work units in order to improve services.

The interpretation of Thomas R. Dye (1978, p. 3) is slightly different from that of Edwards and Sharkansky, public policy as whatever governments choose to do or not to do. While acknowledging the government's role in constituting public policy options, Dye underlined the importance of looking at actions that the government may not have taken. This becomes crucial because, in the context of public policy, inaction is an action as well, and that could have far-reaching implications in public opinion (Oni, 2016). On the other hand, Robert T. Nakamura and Smallwood (1980, p. 31) argued that public policy should consider three environments: the formulation environment, implementation environment, and evaluation environment. They believe that these three environments would explore the ways and the purposes in order to shed light on the instructions given by decision-makers as well as the policy implementation process.

The policy implementation environment is comprised of several actors, yet the type of 
policy should be taken into account. These actors include policymakers, formal implementers, intermediaries, lobbies and constituency groups, recipients and consumers of policies, the media, and evaluators. Nakamura and Smallwood also maintained the links between these three environments through communication and compliance. Communication would make policy formulation and policy implementation work better. Indeed, if communication were ineffective, it would lead to implementation failure. Meanwhile, the policy evaluation environment included those who engage in planning, projections, oversight, or monitoring activities (Nakamura \& Smallwood, 1980).

\section{Figure 1.}

\section{Edwards: Defining variables} of policy implementation

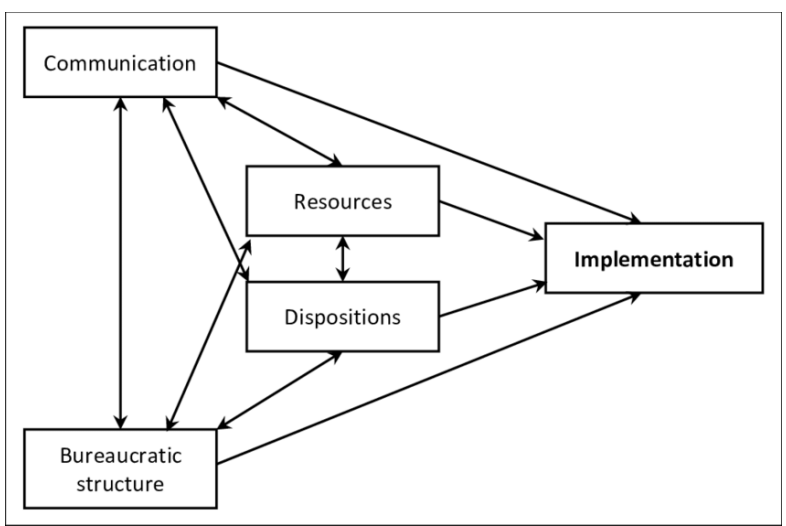

Source: Edwards (1980, p. 148)

Edwards' approach is the most relevant to the aims of this study, given the emphasis it places on assessing the policy implementation in regards to Papua's handling of the COVID-19 pandemic. Although Dye (1978) reminds us about considering inaction the government could take, it may not work in this context because the Papuan government already formulated its policy as a response to the issue. The three environments (the formulation environment, implementation environment, and evaluation environment) proposed by Nakamura and Smallwood in relation to policy implementation also seems not to fit Papuan context. This approach tends to emphasize the role of actors (policymakers and policy implementers) as well as communication and compliance, while ignoring the importance of other aspects. Understanding Papua in the context of handling COVID-19 requires a comprehensive approach, including considering other instruments like resources and bureaucratic structures. Therefore, the frameworks developed by Edwards (communication, resources, dispositions or attitudes, and bureaucratic structures) are highly relevant to assess the implementation of the Papuan government's policy for tackling the spread of COVID-19.

\section{Methods}

This study used a qualitative approach. Data was collected through three different methods, namely interviews, observation, and library research. Data was then analysed using data reduction, data display, and conclusion drawing/verification (Miles \& Huberman, 1994). The researchers conducted interviews with a total of 20 respondents from Jayapura City, Mimika, Biak Numfor, Merauke and Yapen Regency. These five regions were selected because of their characteristics of COVID-19 transmission and their geography in the context of implementing travel restrictions to Papua. Merauke was the first regency in Papua that confirmed its citizens had tested positive for COVID-19. Jayapura city is the capital of Papua Province, making it the center for business and economy. Mimika, the regency where Freeport's Grasberg mine operated, showed frequent travels in and out of Papua and recorded the highest number of positive cases in Papua as of April 2020. Yapen and Biak were picked for geographic concerns, both of which were an island making them difficult to keep their area away from traditional (unofficial) routes of entry. 
The interviewees were chosen because of their knowledge, expertise, and academic competency (appropriateness). They were classified into three clusters: doctors (10 people), academics (8 people), and key figures (2 people). Doctors were those whose expertise and work was related to handling COVID-19, while academics include lecturers based in Cenderawasih University who had competency in the field of public policy, medical science, anthropology, public health, and law. Two key figures, who hold special positions at the national level, were also interviewed in this study because of their knowledge and expertise to understand Papuan cases, namely Expert on Deputy V of the Executive Office of the President of Republic of Indonesia, Laus D.C. Rumayom; and the Member of Commission I of People's Representative Council of the Republic of Indonesia in Electoral District Papua, Yan P. Mandenas. The data collected from the interviews were transcribed. The Papuans interviewed for this study include 13 males and 7 females. At the time of interview, their age ranged between 20 and 30 years (4 people); between 31 and 40 years ( 8 people); between 41 and 50 years (1 person); and over 50 years ( 7 people). Some interviewees agreed to use their real names while others chose to use initials only to remain anonymous.

This study observed the capital of Papua Province, Jayapura City - one of the main epicentres of COVID-19 in the region. Library research was also utilized to collect secondary data in order to strengthen primary data. The secondary data collected in this study were from various sources: 1) Government website/ Documents: Papua Provincial Government, Statistics Indonesia (BPS), The Papua Joint Statement (Kesepakatan Bersama Pencegahan, Pengendalian, dan Penanggulangan COVID-19 di Provinsi Papua); Governor's Letter (Surat Gubernur Papua). 2) News (global, national and local): WHO, TIME, Kompas, The Jakarta Post, BBC News, CNN Indonesia, Tirto, Cepos,
WHO, Lintas Papua, Antara Papua, Suara Papua, Timika Express. 3) Journals related to the topic of COVID-19: Jurnal Ilmu Sosial dan Ilmu Politik, Jurnal Ilmiah Hubungan Internasional, International Journal of Environmental Research and Public Health, Journal of Indonesian Health and Administration, Journal of Chinese Governance. 4) Books related to the theoretical debates, explanation methods, and COVID-19: Tata Kelola Penanganan COVID-19 di Indonesia: Kajian awal, Implementing Public Policy, The Policy Predicament: Making and Implementing Public Policy. This study particularly limited the time for data collection from 22 March to 30 April 2020 due to the ongoing situation with COVID-19 in Papua.

\section{Results}

Results of interviews, observations, and library research are documented below as a summary of local perspectives in response to COVID-19 Papuan policies.

\section{Identification, Response and Policy} Controversies to Restricting Access to Papua

The positive COVID-19 cases in Papua Province were first announced on 22 March 2020 by an acting official of the head of Merauke Regency Health Department, Dr. Nevile Muskita. He confirmed that two of his citizens had tested positive for COVID-19 after receiving the laboratory test results from the National Institute of Health Research and Development in Jakarta. The first patient had a travel history from regions exposed to COVID-19, while the second patient was a medical worker who made direct contact with the infected patient during examination at the Merauke Regional General Hospital (Aditra, 2020). The confirmation of the COVID-19 cases in Merauke Regency and the increase of people under monitoring (ODP) coming from outside Papua had urged the Governor of Papua to organize a meeting on Prevention, Control and Countermeasures of COVID-19 
on 24 March 2020. The meeting, chaired by the Governor himself and attended by Forkopimda, Regents/Mayors, and all stakeholders in Papua, released a 'Joint Statement' to declare the COVID-19 emergency response status by expanding on the central government's social distancing policy for 14 days, starting from 26 March to 9 April 2020. The Papua joint statement stipulated six sections with several points. One of the most eye-catching sections of the statements is to restrict entry into the province both through sea and air travel as well as crossborder posts for a little while- as recorded by section 3 point 6 (Hasil Kesepakatan Bersama, 2020).

The Papua joint statement was fervently supported by Dr. Silwanus Sumule - the spokesperson for the Papua COVID-19 response team. In a video called 'Don't Come to Papua in 14 Days' published by a local media ("Jangan Datang ke Papua dalam 14 Hari", 2020); he asserted "...I knew this could sound harsh for certain people but this was the fact; if you didn't want to die, did not come to Papua. Our ability to manage the COVID-19 patients were very limited in terms of health workers and medical infrastructure. There were only seven pulmonologists and around 60 ventilators in Papua. That's why you would be better off staying in your hometown for a while..." In comparison with other interviews by Jakarta Post (Mawel \& Mambor, 2020) and Tirto (Bernie, 2020), Sumule explained that Papua only had forty-five hospitals, and fifteen of them were recommended as referral hospitals for COVID-19 cases. Furthermore, only two out of the two hundred total isolation rooms across all hospitals in Papua Province met World Health Organization (WHO) standards, whilst the other one hundred and ninety-eight isolation rooms only relied on HEPA filters to limit contamination to indoor air. However, the Indonesian Minister of Home Affairs, Tito Karnavian, disagreed with the Papua joint statement to limit access to the region. He stated that the policy instructions from the central to local government were clear, aiming to prevent the transmission of COVID-19 through social/ physical distancing, not by closing travel from one region to another. On $26 \mathrm{March}$, the Ministry of Transportation (Directorate General of Civil Aviation) also rejected the restricted access, arguing that it should have been started by evaluation, coordination and socialisation (Korwa, 2020).

In contrast to the Ministry of Home Affairs and Transportation, the Member of Commission I of People's Representative Council of the Republic of Indonesia in Electoral District Papua, Yan P. Mandenas (37 years, male), showed his unwavering support for the Papua joint statement to restrict access to the region:

“.. Stayed consistent and continued [to put the statement into practice] even though there were small protests from Jakarta. I thought that the Papuan government, in accordance with the Health Quarantine Law, had taken a step forward to protect the entire community in the land of Papua, so that the positive patients of COVID-19 could be treated intensively and properly, not to mention the importance of socialization. Community quarantine could also be enhanced until the deadline of 14 days or perhaps be extended, so the transmission did not spread across all regencies/city in Papua. This step taken by the governor of Papua should have been underpinned by the central government, thereby breaking the chain of COVID-19 transmission in Papua." (personal communication, 26 March 2020).

By the same token, Expert on Deputy $\mathrm{V}$ of the Executive Office of the President of Republic of Indonesia, Laus D.C. Rumayom (37 years, male) during his visit to the capital of Papua Province also argued: 
"....It should be underlined that the idea of limiting access to Papua was not Mr. Enembe's personal decision, but rather was the result from a joint statement in consultation with Forkopimda along with other stakeholders in Papua including Cenderawasih University, the Health Department of Papua Province, virologists, epidemiologists, medical workers and so forth... Hence, there was no hidden political agenda with the President or the Minister of Home Affairs, it was only an analysis of the situation based on the nature of the virus and how it worked. Restricting people to enter Papua was an effective strategy at that time; imagined if the access had not been closed? Perhaps Papua would have the highest number of confirmed cases due to open access movement and the unpreparedness of health facilities in the region such as rapid tests." (personal communication, 3 May 2020).

The medical staff also endorses the Governor's policy through the joint statement to limit access to the region. According to the interviews with 10 doctors, they all supported the policy because it not only helped them identify people with travel history from outside Papua but it also reduced the positive number of COVID-19 cases from outside Papua. Of ten doctors, six described the transmission of COVID-19 in Papua as 'imported cases'; meaning the virus originated from outside Papua and then local transmission occurred. One of the medical staff, Dr. Agustinus Udam (36 years, male) observed:

“....If I wasn't mistaken, there were two large clusters that contributed to the number of COVID-19 cases in Papua Province - they both were from religious activities, namely cluster GBI (Indonesian Bethel Church), where one or several participants after attending the event in Lembang, West Java then went back home and socialized with other residents, causing a chain of local transmission in Papua became inevitable. Next cluster was from participants who took part in the Ijtima Ulama Gowa event in South Sulawesi..." (personal communication, 6 May 2020).

This is also similar to the statement made by the Regent of Mimika, Eltinus Omaleng, “Initially, COVID-19 did not exist in Mimika and Papua. The day before, the GBI Mawar Sharon Timika congregation joined an event in Lembang; from there the virus spread to Timika when they returned home"(Supar, 2020).

In spite of the support which medical staffs give to the Governor and the joint statement, other measures should be taken into account. According to EF (32 years, female), an epidemiologist from the Faculty of Medicine Cenderawasih University:

"even though the policy made by Enembe in consultation with Forkopimda and other stakeholders was great, it still needed to be accompanied by more aggressive actions such as mass screening especially in red zone areas such as Mimika Regency and Jayapura City. Apart from people under monitoring (ODP) and patient under supervision (PDP), we needed to focus more on asymptomatic person (OTG). These people were moving freely from one place to another. Despite the fact that they could show healthy behavior, they were basically sick and had a high potential for transmission." (personal communication, 5 May 2020).

Indeed, since March 2020 the Ministry of Health has revised the COVID-19 Prevention and Control Guidelines by adding categories of groups of people without symptoms (Adhi, 2020). 
Johni R. V. Korwa, Diego R. De Fretes, Meyland S. F. Wambrauw, Jackson Yumame, Christine O. I. Sanggenafa, Reni Shintasari, Ferinandus L. Snanfi: Assessing the Papuan Government's Policy for Tackling the Spread of

Coronavirus (COVID-19)

The Current Post-Condition of Access Restriction Policy in Papua

In April, the Papua Government has changed its response four times when dealing with the spread of COVID-19: 1) The Instruction of the Governor of Papua No. 1 of 2020, concerning Infection Prevention and Countermeasures of the COVID-19 in Papua Province; 2) The Decree of the Governor of Papua No. 188.4/121/2020, concerning the Establishment of Infection Prevention and Countermeasures Task Force of the COVID-19 in Papua Province; 3) The Circular Letter of the Governor of Papua No. 440/3234 /SET on 16 March 2020, concerning Concrete Steps in efforts to Prevent and Countermeasures the COVID-19 Infection in Papua Province; 4) The Emergency Response announced in the Papua Joint Statement on 24 March 2020. However, it must be acknowledged that the war against COVID-19 is no easy matter - by the time the positive cases of COVID-19 have been discovered in Merauke on 22 March, some people are still being treated while others have recovered or died- as illustrated in the chart below:

Overall, it can be clearly seen that the Papuan's number of positive COVID-19 patients increased over the period of 40 days. In the fourth week of March (22th-31st), the number of COVID-19 patients testing positive was still relatively low with below 15 cases, yet the number then rose dramatically during the period of April which was almost 210 reported cases. This positive upward trend was followed by the category of recovered patients starting

Figure 2.

Comparison between positive, recovery, and death of patients with COVID-19 in Papua Province from 22 March to 30 April 2020

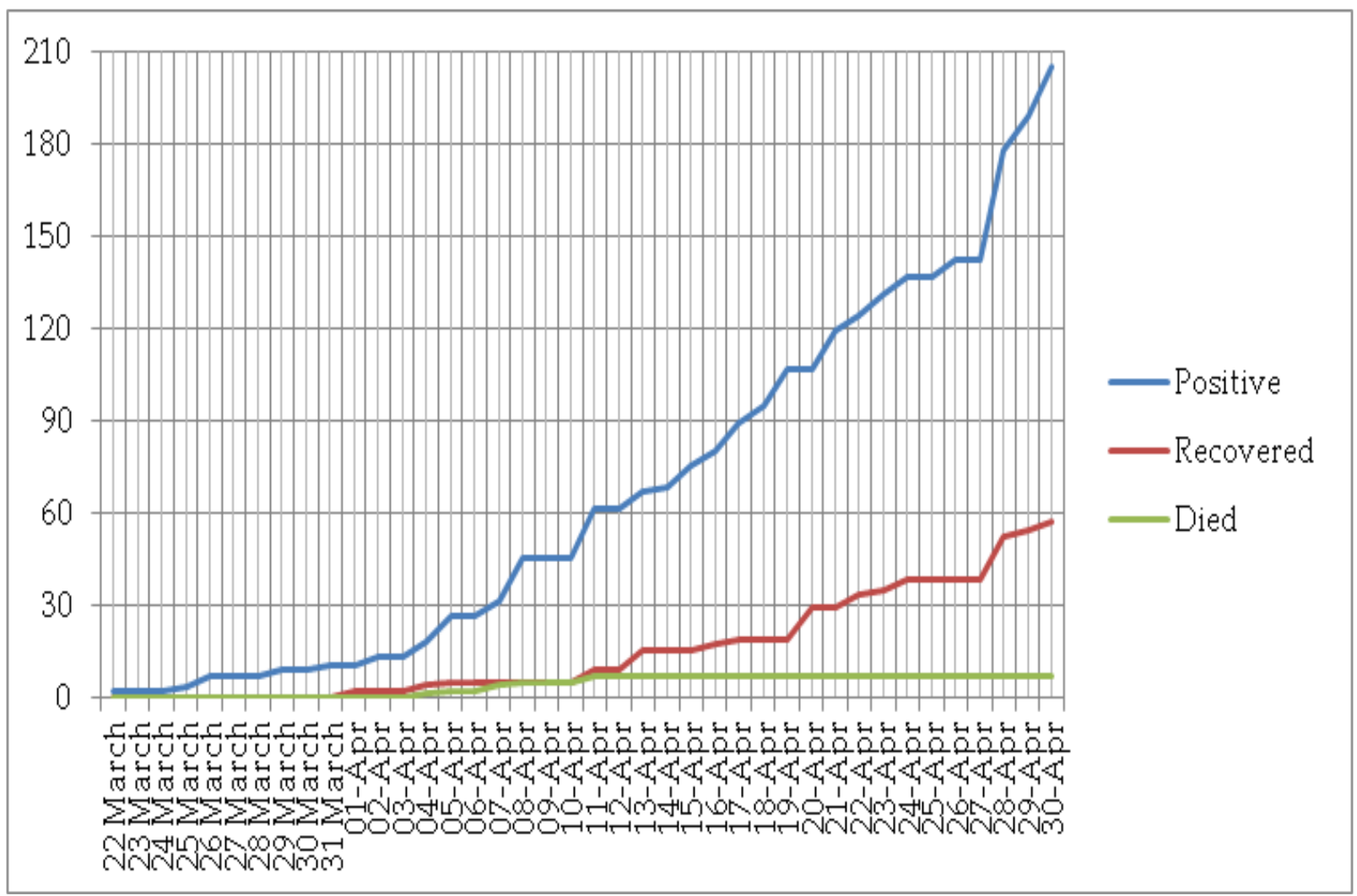

Source: Collected by the authors from 'Satgas Pengendalian Pencegahan Penanganan COVID-19 Provinsi Papua (2020) 
on 01 April; however, the gap between positive and recovered patients remained very large at the end of April, where the number of positive cases was almost four times the number of recovered cases. Meanwhile, the number of confirmed deaths of COVID-19 in Papua remained stable with a total of 7 cases between 10 March and 30 April.

The positive upward trend of COVID-19 cases in the figure above was also stated by one of the interviewees - Hasmi (46 years, female), a lecturer at the Faculty of Public Health, Cenderawasih University who has an epidemiological background. She found the following:

"the COVID-19 cases in Papua were moving exponentially. The case moved at exponential rank numbers. So, the first week in Papua-1 positive case infected 0.14. In week ten, it infected 3.3 people per day. The trend moved exponentially. From the proportion number we ranked the fourth position throughout Indonesia with a prevalence rate. This number was high; several regencies had reached 308/100,000 population. In Papua, there was no sign of stopping or slowing down so far." (personal communication, 5 May 2020).
Indeed, there are many factors which can contribute to the increasing number of positive cases of COVID-19 in Papua. Apart from the limitations of diagnostic tests and other factors, TW (29 years, female) and noname (28 years, male) who worked as doctors in hospitals in Biak Regency and Jayapura City maintained that the patients/suspects, in certain circumstances, did not provide a frank and honest answer related to their travel history and the people they met, so that it became a challenge for them to break the chain of the COVID-19 transmission. They even had to ask repeatedly in order to obtain accurate information (personal communication, 6 May 2020). From a total of the 29 regencies/city in Papua Province, there are 12 regions that have COVID-19 cases, as follows:

The current situation prompts regency and city government to take large measures to reduce the COVID-19 transmission rate in Papua. Based on the observations, for example, Jayapura City through the Task Force for the Prevention and Handling of COVID-19 conducted a rapid test on 30 April 2020 for all vegetable sellers especially those who ride motorbikes and cars to sell their vegetables, in which five merchants were declared reactive to COVID-19 and must undergo self-quarantine

Table 1.

Update COVID-19 Provinsi Papua between 22 March and 30 April 2020

\begin{tabular}{clcccccc}
\hline No & \multicolumn{1}{c}{ Regency/City } & Positive & Hospitalised & Recovered & Died & PDP & ODP \\
\hline 1 & Mimika Regency & 64 & 50 & 11 & 3 & & \\
2 & Jayapura City & 44 & 21 & 20 & 3 & \\
3 & Jayapura Regency & 36 & 25 & 10 & 1 & \\
4 & Nabire Regency & 16 & 16 & 0 & 0 & \\
5 & Merauke Regency & 13 & 5 & 8 & 0 & \\
6 & Keerom Regency & 10 & 8 & 2 & 0 & \\
7 & Biak Regency & 9 & 9 & 0 & 0 & \\
8 & Sarmi Regency & 4 & 1 & 3 & 0 & \\
9 & Jayawijaya Regency & 3 & 1 & 2 & 0 & \\
10 & Mamberamo Tengah Regency & 2 & 1 & 1 & 0 & & \\
11 & Boven Digoel Regency & 2 & 2 & 0 & 0 & & \\
12 & Supiori Regency & 2 & 2 & 0 & 0 & & \\
\hline & Total & 205 & 141 & 57 & 7 & 270 & 1.827 \\
\hline
\end{tabular}

Source: Satgas Pengendalian Pencegahan Penanganan COVID-19 Provinsi Papua (2020) 
as well as taking PCR tests by using swab checks (see also "Cegah COVID-19", 2020). The similar action was also implemented on 24-27 April in Mimika as the region with the highest number of positive cases of COVID-19 in Papua Province as of April, where there were 145 residents reactive to COVID-19 from the whole total of 560 residents that conducted rapid tests ("560 Orang Jalani Rapid Test”, 2020). As PT Freeport Indonesia (PTFI) operated in the region, PTFI had also stopped purchasing or ordering flight tickets to Timika for employees, contractors and family members who would come to the PTFI project area with commercial airlines. This was done to support the Regent's instruction in dealing with the spread of COVID-19 (Jatmiko, 2020). In Jayapura Regency, the government prepared 1,000 rapid tests for the community living around Sentani market. The government has also limited the activities of residents; specifically for supermarkets, shops, mini market, and restaurants - business as usual is only allowed from 08.00 am to $2.00 \mathrm{pm}$, as well as the Pharaa Sentani Market which is restricted between 06.00 am and 2.00 pm ("Aktivitas Masyarakat Dibatasi", 2020; Muhsidin, 2020).

\section{The Impacts and Challenges of Access Restriction Policy to Papua}

A different style of decision-making would certainly have different consequences. These consequences are highly related to policy implementation that deals with actions, programs, and regulations. In this context, it could be argued that Papua government adopted the bottom-up approach to policy decisions in response to COVID-19 prevention. Yet, it has far-reaching implications on the people's lives including social, economic, and cultural aspects. As stated by Septinus Saa (52 years, male), Dean of the Faculty of Social and Political Sciences at Cenderawasih University:

“...The Papua's government policy was an effective strategy..... the problem of COVID-19 was that people had to stay at home, so it could be said that the policy was just like 'The Simalakama fruit' ('jump from the frying pan into the fire' - a phrase which is often interpreted as the most uncomfortable circumstance occurs to a person / experiencing difficulties). In the context of Papua, it meant that the policy restricted people from staying at home while people's activities related to eating and drinking. If they worked as civil servants or middleclass business people, it certainly didn't matter, but if they were lowincome families, this would be a problem because they made a living from their daily activities... Even though the government provided social assistance amidst ongoing COVID-19, it depended on how many people live in the house. It was also worth noting that no one knew when the COVID-19 pandemic would end." (personal communication, 7 May 2020).

Moreover, the restriction access policy also turns out to have a detrimental impact on medical staff as the frontline in combating the spread of COVID-19. As stated by Apter E Patai (51 years, male), Chairperson of Papua's POGI (Indonesian Association for Obstetrics and Gynaecology):

“...Our medical personnel also received bullying and discrimination in the society. When the community knew that they were the doctors or nurses who were part of the COVID-19 team, certain people then became afraid and did not provide services. For example, one of our doctors, who wanted to put his clothes in a laundry service, accepted refusal. Similarly, the one who looked for food stalls also got refused. Even today there had been some parents of nurses who did not allow their children to return home, 
thus the hospital had to prepare a temporary resting place for them." (personal communication, 4 May 2020).

As of 14 April, there have been 2 doctors in Papua who tested positive for COVID-19 (Costa, 2020). Yet, this figure could continue to increase in the months ahead, not only for doctors but nurses as well.

The Papua's government policy also has an impact on economic and cultural aspects. For example, based on our observation in April 2020, the price of eggs in Jayapura city rose significantly. In the first and second week of April, the selling price of eggs in the Hamadi and Youtefa market surged up to $100 \%$. This was mainly because the stock of household staples had decreased on the market. Some traders said that the selling price of broiler eggs which was previously about Rp 58,00060,000 per rack, increased significantly to $\mathrm{Rp}$ $110,000-120,000$ per rack. This condition affects the purchasing power of the community who are generally from the lower class (working class) and still rely on agriculture as the main sector, not to mention the decline in Papua's economic growth. Indeed, in the first quarter of 2020, Papua's economy was minus $6.77 \%$ compared to the fourth quarter of 2019 (Zulkifli, $2020)$, caused by a decline in production in Papua. This economic slowdown was much affected by the spread of the COVID-19 at the end of the first quarter of 2020. Apart from mining and quarrying which are the main sectors of economic income in Papua Province, other sectors which include insurance, financial services, waste management have also experienced a slowdown. Perhaps this is because the government has refocused all budgets on responding to the handling of the Coronavirus, thus slowing down the performance and income of other economic sectors. Additionally, since the temporary shutdown of the RI-PNG border from January
2020, Papua's economic growth has decreased due to the closing of the Skouw market (opportunity lost), reaching IDR 4 billion per month (Bank Indonesia, 2020).

Meanwhile, from a cultural perspective, information regarding the prevention of COVID-19 was not equally disseminated to people in remote areas. In addition to problems of language, geographical condition and lack of internet access/ connection appeared to contribute to the communication problems. Papuans tend to live in groups and rarely use masks so this is a challenge to government policy during this situation. As stated by the Anthropologists at Cenderawasih University, Johsz Mansoben (72 years, male) and Handro Lekitto (51 years, male) that one of the challenges in a cultural perspective was the togetherness of the Papuans in every activity and they would find it difficult to change it in a short time - including shaking hands, gathering for birthdays, family meetings, and so on (personal communication, 26 April 2020).

There are also challenges or criticisms. As stated by a lecturer of the Faculty of Medicine at Cenderawasih University, Gerson Andrew Warnares (33 years, male) related to the time restrictions set by the city/provincial government:

“...Papua's government instruction to limit economic activity especially store opening hours was not effective to eradicate the COVID-19. This could bring a new cluster because many people would gather in one store based on operation hours. The government should have let the stores open as usual. The point was to limit the consumers; not the time. For example, if there were 500 consumers who went shopping in a supermarket, they could then be divided into five groups with each entry was one-hundred consumers." (personal communication, 5 May 2020). 
Another challenge in implementing the policy is also mentioned by one of the doctors (29 years, female) in Kepulauan Yapen regency - an area with no confirmed cases of COVID-19 at the time of writing this article. Even so, they still worked hard to prevent the virus from entering their island. She observed that although the airport and seaport were already closed, there were still speedboats that come from outside to their island and sometimes people were reluctant to provide information and coordination (personal communication, 2 May 2020). This is also raised by Mansoben (72 years, male) from Cenderawasih University that:

"Papua's government policy to restrict access to entry by sea and air was correct, but we must also pay attention to the access through traditional routes (ferries)... Local traders between small islands in Papua must also be banned because their access via the coast and islands could be the cause of the spread of the virus from one region to another." (personal communication, 26 April 2020).

In addition to the problem of monitoring access to informal transportation, Papua also encounters the challenge of sending blood samples between regions during this devastating time as the airport closes. A doctor (37 years, male) from Merauke Regency said that Merauke did not have a proper health laboratory (Labkesda), thereby sending the samples (swab) to Jayapura, Makasar or Jakarta was the only way out. In addition, Merauke only counted on a military cargo aircraft (Hercules) with uncertainty in flight schedules as the airport closed at the moment (personal communication, 2 May 2020). In the next section, the authors will discuss the correlation between national policy regarding large-scale social restrictions (PSBB) towards provincial policy analysis.

\section{Discussion}

Since the Governor released the Papua joint statement in consultation with Forkopimda, regents/mayors, and other stakeholders on March 24, several points have basically been covered through Government Regulation No. 21/2020 on Large Scale Social Restriction (PSBB) as proposed by President Joko Widodo on 31 March. For example, article 4 (1) points (b) and (c) states that 'the PSBB at least includes restrictions on religious activities and restrictions on activities in public places or facilities'. This article has actually been implied in the Papua joint statement section III points (12) and (9) where it refers to 'restricting various forms of worship activities for all religious groups who gather in large numbers, as well as imposing a time of community activity to meet basic needs and other activities in a limited manner from 06:00 am to 2:00 pm'. This topic was also found in interviews with three respondents (a doctor and two lecturers): Patai (51 years, male), EF (32 years, female), and Warnares (33 years, male) - who stated that Papua had already implemented PSBB prior to the policy (PSBB) issued by the President.

Moreover, according to the circular letter from the Governor of Papua number 440/4170/ SET issued on 9 April 2020 concerning prevention, control, and countermeasures of COVID-19 in Papua Province, it was reported that the situation after 14 days of the enactment of the Papua joint statement, and in particular the restriction of airport access and ports throughout Papua, had far-reaching implications for stemming the spread of COVID-19. The Papua government, in this sense, has the ability to contain COVID-19 cases whose sources came from outside Papua (imported cases) and now focuses more on local handling, namely tracking and mapping ODP (people under monitoring) and treatment to PDP (patients under surveillance) who are currently in Papua.

However, the issuance of Government Regulation No. 21/2020 on PSBB has resulted in 
contradictions and illegality of policies which have previously been implemented in Papua. The Government Regulation No. 21 explains that the authority for determination of the PSBB status in a region, including restrictions on the movement of people and goods, resides with the minister who carries out government affairs in the health sector. This is achieved by taking into account proposals that meet the requirements or criteria applicable to article 3 . Hence, it could be argued that Papua is currently implementing an 'illegal' policy because the Minister of Health has not yet officially determined Papua or its regencies/cities in PSBB. It is also worth noting that the criteria stated in Government Regulation No. 21/2020 on PSBB are not clear enough. For example, article 3 (a) states, 'in determining whether a region can put in place PSBB measures, the total number of cases and/ or total number of deaths resulting from illness are increasing and spreading in a significant and swift manner to several regions'. However, this article does not explain in detail how many cases are required quantitatively in order to qualify a region in the status of PSBB. This is vital because, according to some Papuans, the number of COVID-19 cases has been quite high in the region (see figure 1).

While the COVID-19 pandemic remains underway, the Papua government has at least adopted a stricter policy to protect its citizens and the region. To assess the Papuan government's policy, the authors have selected the theoretical frameworks offered by Edwards consisting of four variables. The first of these variables was communication. Edwards and Sharkansky (1978:295) argued "The first requirement for effective implementation is that those responsible for carrying out a decision must know what they are supposed to do. Orders to implement a policy must be ... consistent, clear and accurate in specifying the aims of the decision-makers." This means that the policymaker must clearly understand what he is doing and make sure that his/her instructions can be well interpreted by his subordinates. In the context of Papua Province, it could be said that even though the policy has been formulated at the provincial level, communication between the governor and regent/mayor remains poor. This was conveyed by Ferry Kareth (66 years, male), an academic from the Faculty of Law Cenderawasih University, who stated that "There needs to be more serious coordination between the provincial and regency/city governments in combating the spread of COVID-19 in Papua. The decision-makers in every region must play an active role in communicating and cooperating to break the chain of the virus transmission" (personal communication, 2020, 3 May). The results of this ineffective communication, for example, can be seen in the difference in time restrictions between the provincial and city governments. Despite the deadline set up by the Governor at 2:00 pm for community activities in meeting basic needs, the Mayor of Jayapura adopted a policy of allowing its citizens to perform these activities until 6:00 pm. This clearly shows the implementation of policies that need to be fixed.

The second proposed variable to analyse policy implementation is resources. According to Sarjono and Sulistiadi (2018), resources are divided into four elements namely human resources, budget, facilities, and policy instruments. The organizational structure of the Provincial Government of Papua has sufficient and competent staff, such as the expert staff of the governor and regional secretary, supported by assistants in the fields of government, economic affairs, public welfare, and public affairs. A Papua COVID-19 Task Force has also been formed by the government. Meanwhile, a 2020 special autonomy fund for Papua remains quite large at Rp 5.86 trillion (Pemerintah Provinsi Papua, 2020). Health facilities in Papua are also adequate with the availability of 41 public hospitals across 29 districts/cities in the region (BPS, 2020). Even so, only three hospitals 
in Papua have been proposed by Jakarta for COVID-19 referrals, namely RSU Jayapura, RSU Nabire dan RSU Merauke (Mukaromah, 2020). Papua also has one laboratory testing facility for COVID-19 disease located in Jayapura city. Finally, the policy instruments used by the Papua Province are the Instruction, Decree, and the Governor's Circular as well as the Papua Joint Statement mentioned in the previous discussion. These four resources have shown that Papua is capable of handling COVID-19.

The third proposed variable is disposition. Every leader is expected to not only have the knowledge and capacity related to what they are doing, but they must also be prepared and willing to implement it effectively (Marume et al., 2016). In the context of COVID-19 in Papua, based on observations, interviews and literature studies, it is fair to say that all decision-makers both at the provincial and regency/city levels are working around the clock to break the chain of COVID-19 transmission. For example, Biak Numfor Regent, Herry Ario Naap, has asked his staff to order 2 units of swab specimen inspection equipment made in the United States and Germany for the cost of Rp 2 billion. According to Naap, the method of using rapid tests was considered to be inaccurate and, as a result, made people panic in certain circumstances; not to mention the length in shipping time to Jayapura ("Pemkab Biak Pesan 2 Unit PCR Test", 2020). The decision of the Biak Regent clearly demonstrates how willing and able he is in fighting COVID-19.

The last variable is the bureaucratic structure. As previously explained, there are two main focuses, namely Standard Operational Procedure (SOP) and fragmentation (Cory et. al, 2017; Krisnajaya et al., 2019). Based on the information compiled by the authors, Papua COVID-19 Task Force has treated patients based on the procedure, including burying the deceased in accordance with the SOP, ensuring the complete medical supplies and the construction of a referral hospital for handling COVID-19 in accordance with national program standards. In the context of policy fragmentation, Papua government still needs to improve the way it works. Improving policy implementation includes the provision of social assistance that particularly target those affected by COVID-19. This occurred because of poor coordination between urban villages and the population service and civil registration regarding the data population. The difference in the agreement on hours of activity between regions which have open borders like Jayapura City and Jayapura Regency, has also resulted in confusion for the people living in these two areas. Another reason is that there has been no clarity on sanctions or specific rules for those who break the health protocols and hours of activity. This discouraged the security forces (TNI-Polri dan Satpol PP) from taking decisive action. In short, the bureaucratic structure has also helped support Papua's government policy for tackling COVID-19 despite that some improvements are needed.

\section{Conclusion}

This study has examined stricter COVID-19 Papuan policy by restricting travel to break the spread of the COVID-19 pandemic. Despite some challenges from the central government, this policy is deemed effective by Papuans to protect the region from the virus. Indeed, all respondents in the interviews agreed and appreciated the Papua joint statement to shut down the travels on 26 March 2020. The policy not only helps reduce transmission and death due to COVID-19 (see figure 2), but it also assists the work of medical personnel in focusing on handling local transmissions. In addition, Papua's policy for closing travels has successfully helped the government map the situation in preventing the spread of COVID-19, as mentioned in the letter from the Governor of Papua number 440/4170 / SET concerning prevention, control, 
and countermeasures of COVID-19 in Papua Province.

The theoretical foundation used in this paper also confirmed the effectiveness of policy implementation even though some parts need to be improved. First, communication between the provinces, cities, and regencies has been well established, yet it still needs to be increased. Effective communication is crucial to adopt a similar policy and minimize the discrepancy in policy implementation between regions. Second, the Papuan government resources used to combat COVID-19 have also been effective; they include human resources, budget, facilities, and policy instruments. Third, the disposition to implement policies has been reflected by the leaders in these five regions; one striking example is Biak Numfor Regent Herry Naap, who ordered swab specimens from the United States and Germany. Last, the bureaucratic structure has also helped the way in which the Papua government delivered the policy. The Papua COVID-19 Task Force has conducted its tasks based on the SOP, while improving policy implementation of some programs in the context of fragmentation is still required by the Papua government. It should also be noted that although those five regions have reflected variations between one another in policy implementation, such as Jayapura city where business hours was different with others; Yapen focused on dealing with traditional routes; Merauke with the difficulty of airplane access; Biak lacked swab test kits and plenty of traditional routes; Timika with the operation of PT Freeport made frequent travels to the region; they all have shown how the local government in Papua was doing the best they could to combat COVID-19.

This study offers several suggestions. First, a strong collaboration is needed between provincial and regency/city as well as central government. The expected collaboration particularly includes mutual agreement regarding the hours of activity between provinces and regencies/cities, effective coordination between the sub-district and the population and civil registry offices related to the provision of social assistance, and formal rules (legal sanction) for those breaking the rules. Also, Papua would be better off having an approval from the Ministry of Health to implement PSBB to break the chain of COVID-19 transmission locally. This policy has been successfully implemented in China, called 'a joint response' from central government to local communities (Xioaming, 2020) where the capital city of Hubei Province -Wuhan-along with prefecture-level divisions and township-level divisions (equivalent to cities and regencies) all adopted the same regulations. Second, the need for refocusing the budget in order to increase laboratory testing, particularly in four regions with high case numbers which are geographically separated from one another, namely Mimika, Nabire, Merauke, and Biak. This has also been recommended by WHO (2020), stating that laboratory testing is an integral part of the strategy to mitigate the spread of new cases of COVID-19 in all countries. Third, strengthening the health system response to COVID-19 including protection, health infrastructure improvement, and identification of ODP, OTG, and PDP through surveillance. Finally, simplifying the regulations and adopting an evidence-based policy.

\section{Acknowledgments}

The authors would like to extend thanks to all the 20 interviewees who provided insights critical to the research and made this publication possible. The authors also appreciate the time given by Mr. Mark Cooley (Flinders University), Mr. Petrus Farneubun (University of Groningen) and Mr. Edward Kocu (Cenderawasih University) for reviewing the paper. 
Johni R. V. Korwa, Diego R. De Fretes, Meyland S. F. Wambrauw, Jackson Yumame, Christine O. I. Sanggenafa, Reni Shintasari, Ferinandus L. Snanfi: Assessing the Papuan Government's Policy for Tackling the Spread of

Coronavirus (COVID-19)

\section{References}

560 Orang Jalani Rapid Test, 145 dinyatakan Positif. (2020, April 28). Timika Express. Retrieved from https://timikaexpress. com/2020/04/28/560-orang-jalani-rapidtest-145-dinyatakan-positif/

Adhi, I. S. (2020, April 8). Mengenal OTG, Orang Tanpa Gejala yang Bisa Sebarkan Virus Corona. Kompas. Retrieved from https://health.kompas.com/ $\mathrm{read} / 2020 / 04 / 08 / 140100168 / \mathrm{mengenal-}$ otg-orang-tanpa-gejala-yang-bisasebarkan-virus-corona?page $=$ all

Aditra, I. P. (2020, March 22). Satu Pasien Covid-19 di Merauke adalah Tenaga Kesehatan. Kompas. Retrieved from https://regional.kompas.com/ $\mathrm{read} / 2020 / 03 / 22 / 20520011 / \mathrm{satu}$-pasienpositif-covid-19-di-merauke-adalahtenaga-kesehatan

Aktivitas Masyarakat Dibatasi, Jalan Utama Lengang. (2020). Cepos Online. Retrieved from http://cenderawasihpos.co.id/ aktivitas-masyarakat-dibatasi-jalanutama-lengang/

Almuttaqi, A. I. (2020). Kekacauan Respons terhadap COVID-19 di Indonesia. THC Insights, 1(13), 1-7.

Apresian, S. R. (2020). Responding To the Covid-19 Outbreak in Indonesia: Lessons From European Countries and South Korea. Jurnal Ilmiah Hubungan Internasional, 0(0), 53-57. https://doi. org/10.26593/jihi.v0i0.3868.53-57

Bappeda:Dana Otsus Tahap Pertama Diestimasi Cair Bulan Ini. (2020). Pemerintah Provinsi Papua. Retrieved from https://www. papua.go.id/view-detail-berita-7149/ bappeda-dana-otsus-tahap-pertamadiestimasi-cair-bulan-ini.html

Bernie, M. (2020, March 26). Betapa Tidak Siap Papua Hadapi Corona COVID-19. Tirto. Retrieved from https://tirto.id/betapatidak-siap-papua-hadapi-corona-covid19-eH2S
BPS (2020). Provinsi Papua Dalam Angka. Retrieved from https://papua. bps.go.id/publication/2020/02/28/ d5512728647d2e6a1fa963c0/provinsipapua-dalam-angka-2020--penyediaandata-untuk-perencanaan-pembangunan. html

Cegah COVID-19, Lima Pedagang Sayur Keliling di Kota Jayapura Akan Jalani Tes Swab. (2020, May 2). Lintas Papua. Retrieved from http://lintaspapua.com/2020/05/02/cegahcovid-19-lima-pedagang-sayur-keliling-dikota-jayapura-akan-jalani-tes-swab/

Cory, W.M., Bambang, S., \& Alfi, H. (2017). Policy Implementation of International Undergraduate Program in Indonesia's Higher Education System: A study at Faculty of Economics and Business University of Brawijaya. Russian Journal of Agricultural and Socio-Economic Sciences, 6(66), 199-204. https://doi.org/10.18551/ rjoas.2017-06.23

Costa, F. (2020,A April 14). Dua Dokter PositifCovid-19, IDI Papua Tuntut Penyediaan APD yang Memadai. Kompas. Retrieved from https:// kompas.id/baca/nusantara/2020/04/14/ idi-papua-tuntut-penyediaan-apd-yangmemadai/

Ducharme, J. (2020, March 11). World Health Organizzation Declares COVID-19 a 'Pandemic.' Here's What That Means. TIME. Retrieved from https://time.com/5791661/ who-coronavirus-pandemic-declaration/

Dye, T. R. (1978). Understanding Public Policy. Englewood Cliffs, N.J: Prentice Hall.

Dzulfaroh, A. N. (2020, March 29). Daftar Wilayah di Indonesia yang Terapkan "Local Lockdown." Kompas. Retrieved from https://www.kompas.com/tren/ $\mathrm{read} / 2020 / 03 / 29 / 083900665 /$ daftarwilayah-di-indonesia-yang-terapkan-locallockdown-?page =all

Edwards, G. C. (1980). Implementing Public Policy. Washington DC: Conggresional Quarterly Press. 
Edwards III, G.C., \& Sharkansky, I. (1978). The Policy Predicament. San Fransisco: W.H. Freeman.

Enos, O. (2020). How the Chinese Government Undermined the Chinese People's Attempts to Prevent and Respond to COVID-19. Backgrounder, Asian Study Center, No. 3483, 1-17.

Gorbiano, M. I. (2020, March 02). BREAKING: Jokowi announces Indonesia's first two confirmed COVID-19 cases. The Jakarta Post. Retrieved from https://www. thejakartapost.com/news/2020/03/02/ breaking-jokowi-announces-indonesiasfirst-two-confirmed-covid-19-cases.html

Harus Sentuh Kelas Bawah. (2020, March 31). Koran Fajar Indonesia. Retrieved from https://fin.co.id/wp-content/ uploads/2020/03/EPaper-Koran-FajarIndonesia-Network-Edisi-31-Maret-2020. pdf

Hua, J., \& Shaw, R. (2020). Corona virus (Covid-19) "infodemic" and emerging issues through a data lens: The case of china. International Journal of Environmental Research and Public Health, 17(7). doi: https://doi.org/10.3390/IJERPH17072309

Jangan Datang ke Papua dalam 14 Hari. (2020, March 26). Suara Papua. Retrieved from https://suarapapua.com/2020/03/26/ video-jangan-datang-ke-papua-dalam14-hari/

Jatmiko, B. P. (2020, April 3). Freeport Indonesia Hentikan Penerbangan Penumpang ke Timika. Kompas. Retrieved from https://money.kompas.com/ $\mathrm{read} / 2020 / 04 / 03 / 154658926 /$ freeportindonesia-hentikan-penerbanganpenumpang-ke-timika

Kesepakatan Bersama Pencegahan, Pengendalian, dan Penanggulangan COVID-19 di Provinsi Papua. (2020). Hasil Kesepakatan Bersama (dokumen).

Korwa, J. R. V. (2020). Coronavirus (COVID-19) and Papua 1 : Putting People First. Canberra,
ACT: Dept. of Pacific Affairs, Research School of Pacific and Asian Studies, The Australian National University. https:// doi.org/10.25911/5ec659100053b

Krisnajaya, I. M., Suripto, S., Dewi, N. P., Sulistiyani, A. T., \& Laksana, L.U. A. (2019). The Political Process of Bureaucratic Reform: Wonosobo Regional Government Experience from 2011-2015. Jurnal Ilmu Sosial Dan Ilmu Politik, 23(2), 135-149. https://doi.org/10.22146/jsp.42589

Laboratory Testing Strategy Recommendations for COVID-19. (2020, March 21). WHO. Retrieved from https://www.who.int/ publications-detail/laboratory-testingstrategy-recommendations-for-covid-19interim-guidance

Li Wenliang: Coronavirus kills Chinese whistleblower doctor. (2020, February 07). BBC News. Retrieved from https://www. bbc.com/news/world-asia-china-51403795

Laporan Perekonomian Provinsi Papua Februari 2020. (2020). Bank Indonesia, 5(4). Retrieved from https://www.bi.go. id/id/publikasi/kajian-ekonomi-regional/ papua/Pages/Laporan-PerekonomianProvinsi-Papua-Periode-Februari-2020. aspx

Martha, J. (2020). Pemanfaatan Diplomasi Publik Oleh Indonesia Dalam Krisis Covid-19. Jurnal Ilmiah Hubungan Internasional, 121-130. doi: https://doi.org/10.26593/jihi. v0i0.3859.121-130

Marume, S. B. M., Jubenkanda, R. R., Namusi, C. W., \& Madziyire, N. C. (2016). The Concept of Public Policy Analysis. IOSR Journal of Business and Management (IOSR-JBM), 18(4), 52-58. https://doi. org/10.9790/487X-1804055258

Mawel, B., \& Mambor, V. (2020, March 25). Papua restricts entry as concerns mount over lack of facilities to treat COVID-19. The Jakarta Post. Retrieved from https://www.thejakartapost.com/ news/2020/03/25/papua-restricts-entry- 
Johni R. V. Korwa, Diego R. De Fretes, Meyland S. F. Wambrauw, Jackson Yumame, Christine O. I. Sanggenafa, Reni Shintasari, Ferinandus L. Snanfi: Assessing the Papuan Government's Policy for Tackling the Spread of

Coronavirus (COVID-19)

as-concerns-mount-over-lack-of-facilitiesto-treat-covid-19.html

Miles, M.B., \& Huberman, A.M. (1994). Qualitative Data Analysis: An Expanded Sourcebook. London: SAGE.

Morfi, C. W., Junaidi, A., Elsesmita., Asrini, D. N., Pangest, F., Lestari, D. M., Medison, I., Russilawati., Fauzar., Kurniati, R., \& Yani, F. F. (2020). Kajian Terkini CoronaVirus Disease 2019 (COVID-19). Jurnal Ilmu Kesehatan Indonesia, 1(1), 1-8. https://doi. org/10.25077/jikesi.v1i1.13

Muhsidin. (2020, April 23). Pemkab Jayapura siapkan 1.000 rapid test untuk warga eks pasar lama Sentani. Antara Papua. Retrieved from https://papua.antaranews. com/berita/544280/pemkab-jayapurasiapkan-1000-rapid-test-untuk-wargaeks-pasar-lama-sentani

Mukaromah, V. F. (2020, March 14). Daftar 5 RS Rujukan Corona di Provinsi Papua dan Papua Barat. Kompas. Retrieved from https://www.kompas.com/tren/ $\mathrm{read} / 2020 / 03 / 14 / 210000365 /$ daftar-5-rsrujukan-corona-di-provinsi-papua-danpapua-barat?page $=$ all

Nakamura, R.T., \& Smallwood, F. (1980). The Politics of Policy Implementation. New York: St. Martin's Press.

Nugraheny, D. E. (2020, March 25). Mendagri Tak Setuju Pemprov Papua Tutup Wilayah akibat Covid-19. Kompas. Retrieved from https://nasional.kompas.com/ $\mathrm{read} / 2020 / 03 / 25 / 07591621 /$ mendagri-taksetuju-pemprov-papua-tutup-wilayahakibat-covid-19

Oni, E. O. (2016). Public Policy Analysis (Chapter 15). In Fundamentals of Politics and Governance. Concept Publications Ltd.

Pakpahan, A. K. (2020). Covid-19 Dan Implikasi Bagi Usaha Mikro, Kecil, Dan Menengah. Jurnal Ilmiah Hubungan Internasional, 59-64. https://doi.org/10.26593/jihi. v0i0.3870.59-64
Penutupan Penerbangan dan Pelayaran Khusus Penumpang Masuk Wilayah Papua. (2020, March 24). Surat Gubernur Papua.

Pemkab Biak Pesan 2 Unit PCR Test. (2020b). Cepos Online. Retrieved from https://www. ceposonline.com/2020/05/01/pemkabbiak-pesan-2-unit-pcr-test/

Purnamasari, D. M. (2020, March 15). Jokowi: Saatnya Kerja dari Rumah, Belajar dari Rumah, Ibadah di Rumah. Kompas. Retrieved from https://nasional.kompas. com/read/2020/03/15/14232961/jokowisaatnya-kerja-dari-rumah-belajar-darirumah-ibadah-di-rumah

Sarjono, A. H., \& Sulistiadi, W. (2018). Analysis of Policy Implementation for The Improvement Capability of Internal Government Supervisory Apparatus (APIP) at Inspectorate General of Ministry of Health. Journal of Indonesian Health Policy and Administration, 3(1), 1-8. https:// doi.org/10.7454/ihpa.v3i1.2104

Supar, E. (2020). Bupati Omaleng: Sumber COVID-19 di Mimika dari Cluster Lembang dan Jakarta. Antara Papua. https://papua. antaranews.com/berita/537918/bupatiomaleng-sumber-covid-19-di-mimikadari-cluster-lembang-dan-jakarta

Telaumbanua, D. (2020). Urgensi Pembentukan Aturan Terkait Pencegahan Covid-19 di Indonesia. QALAMUNA: Jurnal Pendidikan, Sosial, Dan Agama, 12(01), 59-70. https://doi.org/10.37680/qalamuna. v12i01.290

Update Corona 23 Maret: 579 Kasus, 49 Meninggal, 30 Sembuh. (2020, March 23). CNN Indonesia. Retrieved from https://www.cnnind onesia.com/ nasional/20200323142245-20-486068/ update-corona-23-maret-579-kasus-49meninggal-30-sembuh

Widaningrum, A., \& Mas'udi, W. (2020). Dinamika Respons Pemerintah Nasional: Krisis Kebijakan Penanganan COVID-19. In Tata Kelola Penanganan COVID-19 di 
Indonesia: Kajian awal (pp. 46-63). Yogyakarta: Gadjah Mada University Press.

Xioaming, L. (2020, April 28). China has valuable lessons for the world in how to fight Covid-19. Financial Tiimes. Retrieved from https:// www.ft.com/content/ad61f0ea-8887-11eaa109-483c62d17528

Yang, H., Bin, P., \& He, A. J. (2020). Opinions from the epicenter: an online survey of university students in Wuhan amidst the COVID-19 outbreak. Journal of Chinese Governance, 5(2), 1-15. https://doi.org/10. 1080/23812346.2020.1745411
Zhu, J. (2020). Is it ethical to be a 'whistleblower' during COVID-19 pandemic? Ethical challenges confronted by health care workers in China. Journal of Advanced Nursing, March, 1873-1875. https://doi. org/10.1111/jan.14376

Zulkifli. (2020, May 7). Akibat Wabah Corona, Perekonomian Papua Triwulan I Minus 6,77 Persen. Pasific Pos. Retrieved from https:// www.pasificpos.com/akibat-wabahcorona-perekonomian-papua-triwulani-minus-677-persen/ 